\title{
Application of the Validated In Vitro Reconstructed Human Skin and Eye Models For Hazard Identification of the Chemical Mixtures
}

\author{
Kimyasal Karışımların Tehlike Tanımlaması İçin Onaylanmış in Vitro Yapılandırılmış İnsan Deri ve Göz \\ Modellerinin Uygulanmas1
}

Yuksel CETIN ${ }^{1}$

\begin{abstract}
The international and national directives and legislation requires to perfom validated in vitro alternative methods to animal testing of chemicals and mixtures for predictible and precise evoluation of toxicity in human. The regulatory agencies require the hazard assessment on skin and ocular as reported by the United Nations, Globally Harmonized System (UN GHS) of Classification and Labeling of Chemicals. To address this need and investigate the usage of alternative methods, the five representative chemical mixtures were prepared in different compositions and their toxicity was evaluated using in vitro validated EpiDerm ${ }^{\mathrm{TM}} \mathrm{SCT}$ for skin corrosion, EpiDerm $^{\mathrm{TM}}$ SIT for skin irritation, and EpiOcular ${ }^{\mathrm{TM}}$ OCL for eye irritation. The tested chemical mixtures 1 and 3 were found corrosive for skin and irritant for both skin and eye. They were identified in the category 1 according to UN GHS. The tested chemical mixtures 2, 4, and 5 were found to be neither corrosive nor irritant to the skin and eye. They were identified in the UN GHS No Category. The potential usage of in vitro Reconstructed Human Epidermis and Cornealike Epithelial as a replacement to animal testing contributed significantly to classify the ocular and skin irritation/corrosion of liquid and solid chemical mixtures and to comply with the regulatory testing requirements. This study confirm that the use of alternative assays instead of conventional in vivo animal test methods could be very reliable and accurate tool to evaluate the skin and eye irritation/corrosion for hazard identification of chemical mixtures.
\end{abstract}

Keywords: Epiderm, Epiocular, Eye irritation, Hazard identification, Skin irritation

\section{öz}

Uluslararası ve ulusal yönetmeliklere ve mevzuata göre, insanda toksisitenin güvenilir ve doğru bir şekilde belirlenmesi için doğrulanmış hayvan deneylerine alternatif in vitro yöntemlerin kullanılmasi gerekmektedir. Düzenleme kurumları deri ve oküler tehlike değerlendirmesinin Kimyasalların Sınıflandırılması ve Etiketlenmesine İlişkin Birleşmiş Billetler, Global Harmonize Sisteme (UN GHS) göre yapılmasını talep etmektedir. Bu ihtiyacı yönelik olarak, hayvan testine alternatif yöntemlerin kullanımını incelemek için beş temsili farklı içeriklerde kimyasal karışım hazırlandı ve toksisiteleri doğrulanmış in vitro EpiDerm TM SCT deri korozyonu, EpiDerm ${ }^{\text {TM }}$ SIT deri irritasyonu ve EpiOcular TM OCL göz irritasyonu modelleri kullanılarak belirlendi. Test edilen 1 ve 3 nolu kimyasal karışımlar, deri için korrosive ve deri ve göz her ikisi içinde irritant olarak bulunmuştur. Bu kimyasallar UN GHS'e göre Kategori 1 olarak sınıflandırılmıştır. Test edilen 2, 4 ve 5 nolu kimyasal karışımların deri ve göz için koroziv ve irritant olmadığı bulunmuştur. UN GHS'ye göre sınıflandırılmayan kategorisinde tanımlanmıştır. Yönetmeliklerde yer alan gereksinimlere göre hayvan deneylerine alternatif in vitro yeniden yapılandırılmış insan epidermis ve kornea benzeri epitel modellerin kullanımı, sıvı ve katı kimyasal karışımların deri ve göz irritasyon/korozyon potansiyelerinin sınıflandırılmasına önemli ölçüde katkıda bulunabilir. $\mathrm{Bu}$ çalışma, kimyasal karışımların tehlike tanımlamasında geleneksel in vivo hayvan deneyleri yerine deri ve göz için koroziv/irritant değerlendirilmesinde alternatif deneyler olarak kullanılabileceğini göstermektedir.

Anahtar Kelimeler: Deri irritasyonu, Epiderm, Epiocular, Göz irritasyonu, Tehlike tanımlanması

\footnotetext{
3Rs Workshop (Replacement, Reduction \& Refinement) Workshop on 2D 3D LIVER \& SKIN REGULATORY MODELS, 2017, TÜBITTAK $M A M$
}

${ }^{1}$ Dr., Yuksel CETIN, Genetic Engineering and Biotechnology Institute, TUBITAK MAM, yuksel.cetin@tubitak.gov.tr, ORCID: 0000-0001$5101-3870$ 


\section{INTRODUCTION}

A wide variety of consumer products such as medical devices, drugs, cosmetics, and chemicals may induce serious skin and eyes irritation or damage as contact with these tissues. Therefore, hazard identification of these products for skin and ocular irritation/corrosion is enforced by the United States (US), European Union (EU) regulatory and Republic of Turkey Ministry of Environment and Urbanization agencies to ensure consumer safety. ${ }^{1}$ Registration, Evaluation, Authorization, and Restriction of Chemicals (REACH) legislation for these variety of agents and products requires an assessment of the skin and ocular irritation future as stated by the United Nations Globally Harmonized System of Classification and Labeling of Chemicals (UN GHS). ${ }^{2}$ Although the evolution of skin and eye irritation/corrosion future of chemicals and products has commonly involved the use of animal testing methods more than 40 years, these in vivo tests has been criticized due to their inadequacy of recreatability, misconception of human responses, and the usage of animals. ${ }^{3}$ These matters have endorsed a number of projects for reduction, refinment and replacement (3Rs) of animal testing. In addition, it was reinforced through the implementation of the $7^{\text {th }}$ Amendment to the Cosmetics Directive prohibited the usage of animals for the safety assessment of cosmetic ingredients and products. $^{4}$ The implementation of $3 \mathrm{Rs}$ in Turkey has been started since 2002. TurkishEU integration attempts have reached dynamism to renovate "Acquis Communautaire" constructed the path to the todays structure. The Turkish Ministry of Agriculture and Rural Affairs disseminated a regulation on the breeding and husbandry of laboratory animals in 2004. All animal facilities have to comformed required technical and operational standards as stated by this directive. Afterwards, in 2006, Turkish Ministry of Environment and Forestry disseminated the regulation on Laboratory Animals Ethics Committees and settled the "National Ethics Committee for Animal Experiments".

The European Union Reference Laboratory European Centre for the Validation of Alternative Methods (EURL ECVAM's) assessed the relevance and reliability of the in vitro skin and eye irritation/corrosion assays, which are broadly applicable, straight usage, and economic methods. ${ }^{5}$ The validated three-dimensional (3D) reconstructed human epidermis; EpiSkin $^{\mathrm{TM}}$, SkinEthic ${ }^{\mathrm{TM}}$ RHE, epiCS ${ }^{\circledR}$, EpiDerm $^{\mathrm{TM}}$, and LabCyte EPI-MODEL24 are mimics the morphological, and biochemical characteristics of the outher layer of the human skin. They provides the evaluation of skin irritation/corrosion futures of chemicals and mixtures according to the UN GHS. ${ }^{2}$

The two validated 3D RhCE tissues are reconstructed from primary human transfected corneal epithelial cells (SkinEthic $^{\text {TM }} \mathrm{HCE} / \mathrm{S}$ ) and from human epidermal keratinocytes (EpiOcular ${ }^{\mathrm{TM}}$ OCL200) measure cytotoxicity occured throughout the production of cell and tissue damage in the cornea due to penetration of the chemicals. ${ }^{6,7}$ To replace the in vivo animal testing, many alternative tissue models have been developed but several of them have been validated and officially approved as test guidelines (TGs) via the Organization for Economic Cooperation and Development (OECD). ${ }^{8}$

The aim of this study to explore the application of validated in vitro 3D human reconstructed models of eye and skin for the hazard identification of the five representative chemical mixtures. The validated EpiDerm ${ }^{\mathrm{TM}}$ SCT, EpiDerm ${ }^{\mathrm{TM}}$ SIT and EpiOcular ${ }^{\mathrm{TM}}$ OCL models were selected as the in vitro testing models because of their broad relevancy to different types of chemicals, medical devices, cosmetics, and mixtures. The increased usage of validated in vitro systems as animal alternatives may explore their development and validation studies. 


\section{MATERIALS AND METHODS}

This study supported by Marmara Research Center Foundation with the project number of 57A3101.

\section{In Vitro Skin Corrosion}

In vitro EpiDerm ${ }^{\mathrm{TM}} \mathrm{SCT}$ reconstructed from human derived epidermal keratinocytes, $\mathrm{RhE}$ was purchased from MatTek Corporation, Bratislava, Slovakia (Figure 1). Following the application of the chemicals mixtures in the Table 1 , the occurance of irreversible adverse effects to the skin revealed as noticeable tissue death on the epidermis and into the dermis indicated as skin corrosion. This test allowed the classification of non-corrosive and corrosive chemical mixtures. The assay was carried out as guided by the OECD TG 431 and the details of the method was given in the Table $2 .{ }^{9}$

Table 1. The Compositions of the Chemical Mixtures Tested by Using in Vitro Reconstructed Skin and Eye Models.

\begin{tabular}{lr}
\hline Chemical mixtures, CM & \% $^{*}$ \\
\hline Chemical mixture 1 (CM 1), solid & \\
Polycarbonate (p\#** GF65553598) & 10.7 \\
$\begin{array}{l}\text { Potasium nitrate (p\# 221295) } \\
\text { Ironoxide (p\# GF37175665) }\end{array}$ & 64.3 \\
Magnesium carbonate & 7.1 \\
Hydroxypentahydrate (p\# M5671) & 17.9 \\
\hline Chemical mixture 2 (CM 2), solid & \\
Terephthalic acid (p\# 490849) & 35.0 \\
Potasium chlorate (p\# 255572) & 28.0 \\
Sucrose (p\# 94474) & 17.0 \\
Magnesium carbonate & 20.0 \\
Hydroxypentahydrate & \\
\hline Chemical mixture 3 (CM 3), solid & \\
2,4-Dichlorobenzylidene-Malono nitrile & 35.0 \\
(p\# S531715) & 25.0 \\
Potasium chlorate & 25.0 \\
Sucrose & 15.0 \\
Hydromagnesite (p\# 1.05827) & \\
\hline Chemical mixture 4 (CM 4), liquid & \\
Oleoresin capsicum (p\# M2028) & \\
Propylene glycol (p\# W294004) & 39.3 \\
Isopropyl alcohol (p\# W292907) & 60.0 \\
\hline Chemical mixture 5 (CM 5), liquid & \\
Capsaisin & \\
Propylene glycol & \\
Isopropyl alcohol & \\
${ }^{* *}$ Percentage in the chemical mixture & \\
p\#: Product number & \\
& \\
\hline
\end{tabular}

Briefly, the liquid or solid tested chemical mixtures was prepared and added to the upper sides of the tissue insert $\left(0.63 \mathrm{~cm}^{2}\right)$ in the 24-well plate. It was incubated either 3 min at $25{ }^{\circ} \mathrm{C}$ or $60 \mathrm{~min}$ exposure time at 37 ${ }^{\circ} \mathrm{C}, 5 \% \mathrm{CO}_{2}$. Following the treatments, the inserts were washed with Dulbecco's Phosphate Buffered Saline (DPBS, p\# 8537) several times. The cell viability was investigated by adding $300 \mu \mathrm{l}$ of medium including $10 \%$ of MTT (3-(4,5dimethylthiazol-2-yl)-2,5-diphenyltetrazol ium bromide) (p\# M5655, SigmaAldrich) dissolved in DPBS $(1 \mathrm{mg} / \mathrm{ml})$. The mitochondrial enzymes of the viable cells can convert the yellow MTT into a blue formazan salt. After 3 hrs disolving of formazan salt from the tissues with dimethyl sulfoxide (p\# D8418), It was quantitatively measured at $570 \mathrm{~nm}$ with microplate reader.

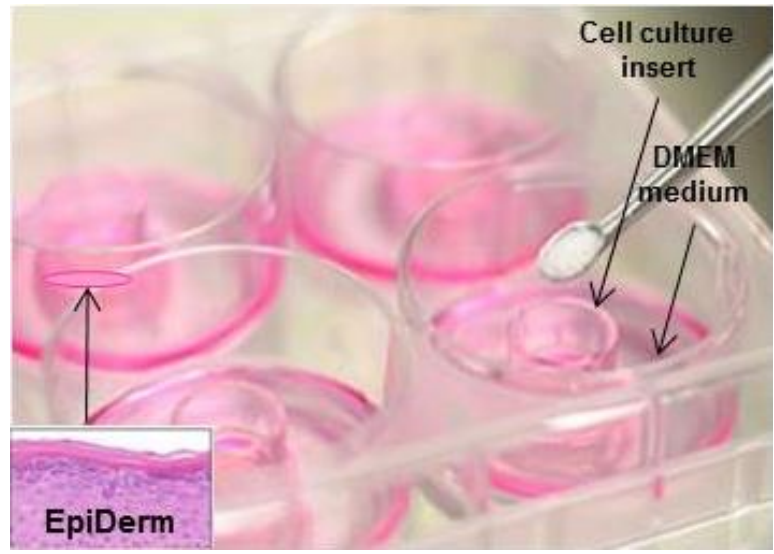

Figure 1. In vitro EpiDerm ${ }^{\mathrm{TM}}$ reconstructed from human derived epidermal keratinocytes, RhE (MatTek Corporation, Bratislava, Slovakia). ${ }^{9}$

\section{In Vitro Skin Irritation}

The prepared chemical mixtures which were given in the Table 1 placed topically to the EpiDerm ${ }^{\mathrm{TM}}$ SIT tissues consisting human derived non-transformed and highly differentiated epidermal keratinocytes was purchased from MatTek Corporation, Bratislava, Slovakia. It mimics the in vivo main intercellular lamellar lipid layers composed of a multilayered stratum corneum. In vitro skin irritation using EpiDerm $^{\text {TM }}$ SIT was carried out as described by OECD TG 439 and the details of the 
method was given in the Table 2. ${ }^{10}$ After treatment and post-treatment incubation periad of the tissues, if the tissue viability was $\leq$ to $50 \%$, the tested chemical mixtures were classified as Category 2 or 1 as defined by the UN GHS.

\section{In Vitro Eye Irritation}

The prepared chemical mixtures given in the Table 1 were applied topically to the EpiOcular ${ }^{\mathrm{TM}}$ corneal model (OCL-200, MatTek Corporation, Ashland, MA). It is derived from the human epidermal keratinocytes which mimics the form a stratified, squamous epithelium found in the cornea. The assay was carried out as defined by the OECD TG 492 and the details of the method was given in the Table 2. ${ }^{11}$ The method was applied to assess the eye hazard characteristics of the tested chemical mixtures based on their adverse effects on the in vitro validated EpiOcular cornea model, measured by the tetrazolium dye. The viability of the tissues following exposure to the tested chemical mixtures was analyzed in comparison with the tissues treated with the negative control substance which was set to $100 \%$ viability.

\section{Aspect of Research Ethics}

In this study, an ethics committee application is not required, as the study was conducted on commercial in vitro models.
This research has been conducted in the laboratory of TUBITAK, Marmara Research Center, Genetic Engineering and Biotechnology Institute. The instituonal permission for this study was received on October 28, 2020.

\section{Data Analysis}

The data of the mean values and the standard deviations of the 3 replicates was calculated with Microsoft Excel 2016 and presented as mean \pm Stdev. The graphs for each in vitro models were drawn with the Microsoft Excel program. The significance for each method was considered according to the standards given in the each of the applied methods.

\section{Limitation of Research}

This study was carried out using validated in vitro models which could not be easily available in Turkey. These models needs to be imported from aboard. In addition, they have very short shelf life for their usage.

\section{Conflict of Interest}

There was not any conflict of interest which was declared by the author.

\section{Financial Disclosure}

This research was supported by TUBITAK, Marmara Research Center Foundation.

Table 2. Test Methods of the in vitro Validated Epiderm ${ }^{\mathrm{TM}}$ SCT for Skin Corrosion, Epiderm ${ }^{\mathrm{TM}}$ SIT for Skin Irritation, and EpiocularTM OCL for Eye İrritation.

\begin{tabular}{|c|c|c|c|}
\hline $\begin{array}{l}\text { Test Method } \\
\text { Components }\end{array}$ & EpiDerm SCT & EpiDerm SIT & EpiOcular OCL \\
\hline Model surface & $0.63 \mathrm{~cm}^{2}$ & $0.60 \mathrm{~cm}^{2}$ & $0.60 \mathrm{~cm}^{2}$ \\
\hline $\begin{array}{l}\text { Number of } \\
\text { tissue replicates }\end{array}$ & $\begin{array}{l}\mathrm{n}=3 \text { tissues used for each } \\
\text { chemical mixture }\end{array}$ & $\begin{array}{l}\mathrm{n}=3 \text { tissues used for each } \\
\text { chemical mixture }\end{array}$ & $\begin{array}{l}\mathrm{n}=3 \text { tissues used for } \\
\text { each chemical mixture }\end{array}$ \\
\hline $\begin{array}{l}\text { Exposure doses } \\
\text { and treatment }\end{array}$ & $\begin{array}{l}\text { Liquids: } 50 \mu \mathrm{l} \text { or } 79.4 \mu \mathrm{l} / \mathrm{cm}^{2} \\
\text { Solids: } 25 \mu \mathrm{l} \mathrm{H} \mathrm{H}_{2}+25 \mathrm{mg} \\
\left(39.7 \mathrm{mg} / \mathrm{cm}^{2}\right)\end{array}$ & $\begin{array}{l}\text { Liquids: } 50 \mu \mathrm{l} \text { or } 83.3 \mu \mathrm{l} / \mathrm{cm}^{2} \\
\text { Solids: } 50 \mathrm{mg} \text { or } 83.3 \\
\mathrm{mg} / \mathrm{cm}^{2}\end{array}$ & $\begin{array}{l}\text { Liquids: } 50 \mu \mathrm{l} \text { or } 83.3 \\
\mu \mathrm{l} / \mathrm{cm}^{2} \\
\text { Solids: } 50 \mathrm{mg} \text { or } 83.3 \\
\mathrm{mg} / \mathrm{cm}^{2}\end{array}$ \\
\hline $\begin{array}{l}\text { Exposure time } \\
\text { and temperature }\end{array}$ & $\begin{array}{l}3 \mathrm{~min} \text { at } 25^{\circ} \mathrm{C} \text {, and } 60 \mathrm{~min} \\
\text { at } 37^{\circ} \mathrm{C}, 5 \% \mathrm{CO}_{2}\end{array}$ & $\begin{array}{l}\text { Liquids: } 30 \mathrm{~min} \\
\text { Solids: } 6 \mathrm{hrs} \\
\text { at } 37^{\circ} \mathrm{C}, 5 \% \mathrm{CO}_{2} \\
\text { in culture medium }\end{array}$ & $\begin{array}{l}\text { Liquids: } 30 \mathrm{~min} \\
\text { Solids: } 6 \mathrm{hrs} \\
\text { at } 37^{\circ} \mathrm{C}, 5 \% \mathrm{CO}_{2} \\
\text { in culture medium }\end{array}$ \\
\hline Rinsing & 20 times with DPBS ${ }^{*}$ & $\begin{array}{l}3 \text { times in } 100 \mathrm{ml} \text { of } \\
\mathrm{Ca}^{+} / \mathrm{Mg}^{+} \text {free DPBS }\end{array}$ & $\begin{array}{l}3 \text { times in } 100 \mathrm{ml} \text { of } \\
\mathrm{Ca}^{2+} / \mathrm{Mg}^{2+} \text { free DPBS }\end{array}$ \\
\hline $\begin{array}{l}\text { Post-exposure } \\
\text { preoccupation }\end{array}$ & - & $\begin{array}{l}\text { Liquids: } 12 \mathrm{~min} \\
\text { Solids: } 25 \mathrm{hrs} \\
\text { at } \mathrm{RT}^{* *} \text { in culture medium }\end{array}$ & $\begin{array}{l}\text { Liquids: } 12 \mathrm{~min} \\
\text { Solids: } 25 \mathrm{hrs} \\
\text { at RT in culture medium }\end{array}$ \\
\hline
\end{tabular}




\begin{tabular}{|c|c|c|c|}
\hline $\begin{array}{l}\text { GÜSBD 2021; 10(2): } \mathbf{1 8 6} \text { - } 193 \\
\text { GUJHS 2021; 10(2): } 186-193\end{array}$ & \multicolumn{2}{|c|}{$\begin{array}{l}\text { Gümüşhane Üniversitesi Sağlık Bilimleri Dergisi } \\
\text { Gümüşane University Journal of Health Sciences }\end{array}$} & $\begin{array}{r}\text { Araştırma Makalesi } \\
\text { Original Article } \\
\end{array}$ \\
\hline \multicolumn{4}{|l|}{ Table 2 continue } \\
\hline $\begin{array}{l}\text { Post-exposure } \\
\text { incubation }\end{array}$ & - & $\begin{array}{l}\text { Liquids: } 120 \mathrm{~min} \\
\text { Solids: } 18 \mathrm{hrs} \\
\text { at } 37^{\circ} \mathrm{C}, 5 \% \mathrm{CO}_{2} \\
\text { in culture medium }\end{array}$ & $\begin{array}{l}\text { Liquids: } 120 \mathrm{~min} \\
\text { Solids: } 18 \mathrm{hrs} \\
\text { at } 37^{\circ} \mathrm{C}, 5 \% \mathrm{CO}_{2} \\
\text { in culture medium }\end{array}$ \\
\hline Negative control (NC) & $50 \mu \mathrm{l} \mathrm{H}_{2} \mathrm{O}$ & $50 \mu \mathrm{l} \mathrm{H}_{2} \mathrm{O}$ & $50 \mu \mathrm{H}_{2} \mathrm{O}$ \\
\hline Positive control (PC) & $50 \mu \mathrm{l} 8 \mathrm{~N} \mathrm{KOH}$ & $50 \mu l$ Methyl acetate & $50 \mu l$ Methyl acetate \\
\hline MTT solution & $300 \mu \mathrm{l}(1 \mathrm{mg} / \mathrm{ml})$ & $300 \mu \mathrm{l}(1 \mathrm{mg} / \mathrm{ml})$ & $300 \mu \mathrm{l}(1 \mathrm{mg} / \mathrm{ml})$ \\
\hline $\begin{array}{l}\text { MTT incubation } \\
\text { time \& temperature }\end{array}$ & $180 \mathrm{~min}$ at $37^{\circ} \mathrm{C}, 5 \% \mathrm{CO}_{2}$ & $180 \mathrm{~min}$ at $37^{\circ} \mathrm{C}, 5 \% \mathrm{CO}_{2}$ & $\begin{array}{l}180 \text { min at } 37^{\circ} \mathrm{C}, 5 \% \\
\mathrm{CO}_{2}\end{array}$ \\
\hline $\begin{array}{l}\text { Extraction } \\
\text { solvent }\end{array}$ & Isopropanol, $2 \mathrm{ml}$ & Isopropanol, $2 \mathrm{ml}$ & Isopropanol, $2 \mathrm{ml}$ \\
\hline $\begin{array}{l}\text { Extraction time } \\
\text { and temperature }\end{array}$ & $\begin{array}{l}\text { mixing at } 120 \mathrm{rpm} \\
\text { at } 25^{\circ} \mathrm{C} \text { for } 2-3 \mathrm{hrs}\end{array}$ & $\begin{array}{l}\text { mixing at } 120 \mathrm{rpm} \\
\text { at } 25^{\circ} \mathrm{C} \text { for } 2-3 \mathrm{hrs} \\
\end{array}$ & $\begin{array}{l}\text { mixing at } 120 \mathrm{rpm} \\
\text { at } 25^{\circ} \mathrm{C} \text { for } 2-3 \mathrm{hrs}\end{array}$ \\
\hline OD reading & $570 \mathrm{~nm}$ & $570 \mathrm{~nm}$ & $570 \mathrm{~nm}$ \\
\hline $\begin{array}{l}\text { Tissue Quality } \\
\text { Control }\end{array}$ & $\begin{array}{l}\text { Using Triton } X-100 \text { in } \\
100 \mu \mathrm{l} \text { of } 0.3 \%(\mathrm{v} / \mathrm{v}) \\
4 \mathrm{hrs} \leq \mathrm{ET}_{50}{ }^{* * *} \leq 8.7 \mathrm{hrs}\end{array}$ & $\begin{array}{l}\text { Using Triton } \mathrm{X}-100 \text { in } \\
100 \mu \mathrm{l} \text { of } 0.3 \%(\mathrm{v} / \mathrm{v}) \\
12.2 \min \leq \mathrm{ET}_{50} \leq 37.5 \mathrm{~min}\end{array}$ & $\begin{array}{l}\text { Using Triton } X-100 \text { in } \\
100 \mu l \text { of } 0.3 \%(\mathrm{v} / \mathrm{v}) \\
12.2 \min \leq \mathrm{ET}_{50} \leq 37.5 \\
\min \end{array}$ \\
\hline $\begin{array}{l}\text { Acceptability } \\
\text { Criteria }\end{array}$ & $\begin{array}{l}\text { Optical density of the tissues } \\
\text { exposed to the negative } \\
\text { control should be } \\
\geq 0.8 \text { and } \leq 2.8 \text {. } \\
\text { Percent viability of the } \\
\text { tissues eposed to the positive } \\
\text { control for } 1 \mathrm{hr} \text { defined as } \% \\
\text { of the negative control } \\
\text { should be } \leq 15 \%\end{array}$ & $\begin{array}{l}\text { Optical density of the } \\
\text { tissues exposed to the } \\
\text { negative control should be } \\
>0.8 \text { and }<2.5 \text {. } \\
\text { Percent viability of the } \\
\text { tissues exposed to the } \\
\text { positive control for } 6 \mathrm{hrs} \\
\text { defined as } \% \text { of the } \\
\text { negative control should be } \\
<50 \%\end{array}$ & $\begin{array}{l}\text { Optical density of the } \\
\text { tissues exposed to the } \\
\text { negative control should } \\
\text { be } \\
>0.8 \text { and }<2.5 \\
\text { Percent viability of the } \\
\text { tissues exposed to the } \\
\text { positive control ( } 30 \\
\text { min for liquids and } 6 \\
\text { hrs for solids) defined } \\
\text { as } \% \text { of the negative } \\
\text { control, should be }< \\
50 \%\end{array}$ \\
\hline
\end{tabular}

\section{RESULTS AND DISCUSSION}

\section{In Vitro Skin Corrosion}

The occurance of unreversible adverse effects to the skin revealed as noticeable tissue death over the epidermis and into the dermis is defined as skin corrosion following exposure to the chemicals and the other products. RhE Test Method using EpiDerm $^{\mathrm{TM}}$ SCT contributes the classification of non-corrosive, corrosive, and also partial sub-categorisation in accordance with UN GHS. ${ }^{12}$ When CM 1 and CM 3 was applied to the in vitro EpiDerm tissues, the tissue viability was resulted in < $50 \%$ and $<15 \%$ after exposure for $3 \mathrm{~min}$ and $60 \mathrm{~min}$, respectively. Therefore, CM 1 and CM 2 were corrosive and placed in the category 1A. The tissue viability upon exposure to $\mathrm{CM} 2, \mathrm{CM} 4$, and $\mathrm{CM} 5$ for 3 $\min$ and $60 \mathrm{~min}$ were found $\geq 50 \%$ and $\geq$ $15 \%$, respectively. The corrosive and noncorrosive compounds were shown in the

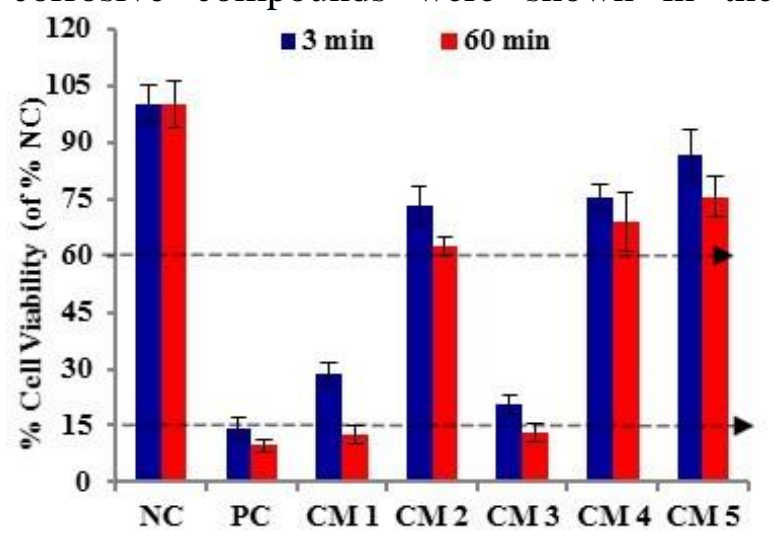

Figure 2.

Figure 2. In Vitro Skin Corrosion Test Results Obtained by Using EpiDerm ${ }^{\mathrm{TM}}$ Tissues $(n=3)$ for 5 Chemical Mixtures (CM), NC and PC. ${ }^{12}$ 
The in vitro skin corrosin, RhE Method contributes significantly in analyzing the skin corrosion future of a wide range of liquid and solid chemical mixtures as stated by the UN GHS. Deprez et al. (2015) comfirmed the predictive potential of EpiDerm tissue model by testing corrosivity potential of the 80 chemicals comparing the results with the other in vitro tissue models such as EpiSkin $^{\mathrm{TM}}$ SkinEthic ${ }^{\mathrm{TM}}$ and epiCS ${ }^{\circledR} .^{12}$ In addition, tis model allows allowtranslating those values into sub-categories of corrosive chemicals.

\section{In Vitro Skin Irritation}

It is based on the in vitro test model of $\mathrm{RhE}$ which represents the upper layer of the human skin and their biochemical and physiological properties. The mean percent of the tissue viability after exposure to the tested CM1, and CM 3 was less than $(\leq)$ $50 \%$. Therefore, the tested CM 1, and CM 3 were identified as skin irritants in the category 2 according to UN GHS. The tissue viability after exposure to the tested CM 2, $\mathrm{CM} 4$, and CM5 was found more than (>) $50 \%$ as compared with the negative control $\left(\mathrm{H}_{2} \mathrm{O}\right)$. In accordance with UN GHS, these mixtures were classified in the no-categotry as non-irritants to the skin and identified in the no Category (Figure 3).

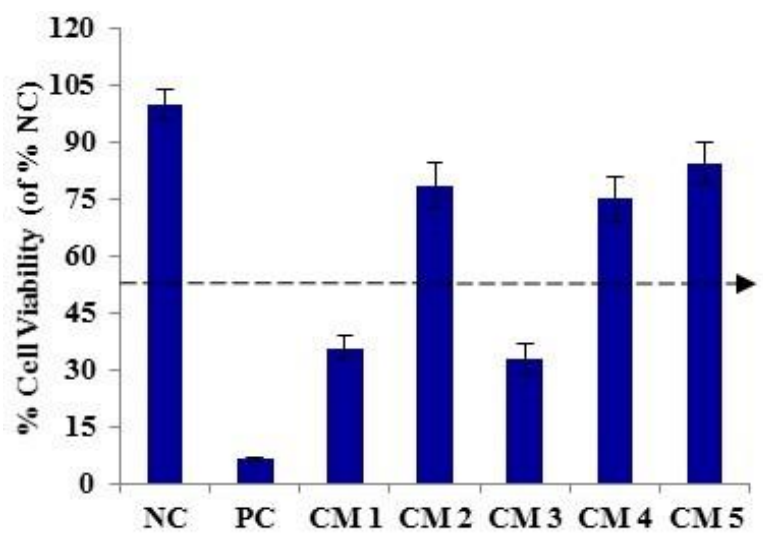

Figure 3. In Vitro Skin Irritation Results Obtained by Using EpiDerm ${ }^{\mathrm{TM}}$ Tissues $(\mathrm{n}=3)$ for 5 Chemical Mixtures (CM), NC and PC. ${ }^{13}$

In the another study, the capacity of EpiDerm tissue model to address the skin irritation potential of medical devices was also demonstrated comparing with conventional
Draize rabbit skin irritation test. ${ }^{13}$ The result of this study comfirmed our findings.

\section{In Vitro Eye Irritation}

The serious eye damage may occurs upon treatment of the eye to a test chemical due to severe physical impairment of vision. If it is not fully reversible, the chemical is defined in the UN GHS Category 1. On the other hand, if the induction of eye irritation are fully reversible, these chemicals and mixtures are determined as UN GHS Category 2. When the test chemicals are not classified for serious eye damage eye or irritation, they are assigned to as UN GHS No Category.

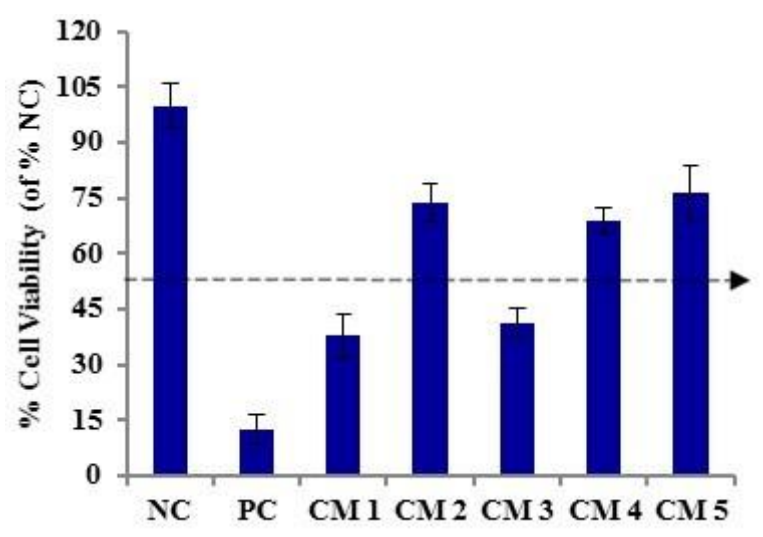

Figure 4. In Vitro Eye Irritation Results Obtained by Using EpiOcular ${ }^{\mathrm{TM}}$ Tissues $(\mathrm{n}=3)$ for 5 Chemical Mixtures (CM), NC and PC. ${ }^{13}$

The mean percent tissue viability after exposure to the tested CM1 and CM 3 was less than $(\leq) 50 \%$. They were eye irritants and identified as category 1 according to UN GHS. The tissue viability after exposure to the tested CM 2 CM 4 and CM5 was more than (>) 50\%. These mixtures were considered as non-irritant to the eyes as defined by the UN GHS No Category (Figure 4). In another study, the eye irritation potential of 20 nanosized materials using in vitro EpiOcular tissue model was assessed. ${ }^{14}$ The findings showed that the model allowed to determine the irritation potential of these materials as obtained from our study. EpiOcular tissue model was also used to evaluate eye irritation potential of medical devices. ${ }^{15}$ The results showed that this model can be replaced the concentional in vivo test for medical devices. 


\section{CONCLUSION}

This study was carried out to explore the use of validated in vitro tissue models as animal testing alternatives. In addition, these in vitro models are generally used for single chemical/product whereas they are rarely used for mixtures for hazard identification. This study was also confirmed the usefullness of these in vitro models for chemical mixtures.

The implementation of 3Rs in Turkey, in the process of grant application to TÜBITAK which has required ethics committee approval from the researchers, Turkish- EU integration attemps have increased dynamism and the restructure to integrate "Acquis Communautaire" builded since 2002. The Ministry of Agriculture and Rural Affairs disseminated a regulation on the breeding and husbandry of laboratory animals in 2004. According to this regulation, all animal facilities have to supply required technical and operational needs. Consequently, in the aspects the implementation of the 3R principles, the Ministry of Environment and Forestry declared the regulation on Laboratory Animals Ethics Committees and established the "National Ethics Committee for Animal Experiments" in 2006.

There is a need to develop and validate in vitro models for testing consumer products such as medical devices, drugs, cosmetics, and a number of chemicals and mixtures that may cause severe acute and chronic damage in the variety organs and in the environment. In addition, it is very important to collabrate with the international research centers in the process of validation of the in vitro organ models due to their very crucial usaage at the research base and also at the regulatory requirements stage.

\section{REFERENCES}

1. National Toxicology Program. (NTP). (2007). "Interagency Center for the Evaluation of Alternative Toxicological Methods (NICEATM); Request for Ocular Irritancy Test Data From Human, Rabbit, and In Vitro Studies Using Standardized Testing Methods". Fed Reg, 72, 31582-31583.

2. U.N. (2017). "United Nations Globally Harmonized System of Classification and Labelling of Chemicals (GHS). ST/SG/AC.10/30/Rev.7, Seventh Revised Edition, New York and Geneva: United Nations". Available at: [http://www.unece.org/fileadmin/DAM/trans/danger/publi/ghs/ ghs_rev07/English /ST-SG-AC10-30- Rev7e.pdf].

3. Adriaens, E. (2014). "Retrospective Analysis of the Draize Test for Serious Eye Damage/Eye İrritation: Importance of Understanding The in Vivo Endpoints Under UN GHS/EU CLP for The Development and Evaluation of in Vitro Test Methods". Arch Tox, 88, 701-723.

4. European Commission. (2006). "Regulation (EC) No 1907/2006 of the European Parliament and of the Council of 18 December 2006 Concerning the Registration, Evaluation, Authorisation and Restriction of Chemicals (REACH), Establishing A European Chemicals Agency, amending Directive 1999/45/EC and Repealing Council Regulation (EEC) No 793/93 and Commission Regulation (EC) No 1488/94 as well as Council Directive 76/769/EEC and Commission Directives 91/155/EEC, 93/67/EEC, 93/105/EC and 2000/21/EC OJ”. L396 (49), 1-849.

5. Pfannenbecker, U. (2013). "Cosmetics Europe MultiLaboratory Pre-Validation of the EpiOcular Reconstituted Human Tissue Test Method for the Prediction of Eye Irritation”. Toxicol In Vitro, 27 (2), 619-626.
6. Kaluzhny, Y, Kandárová, H, Hayden, P, Kubilus, J, d'Argembeau-Thornton, L. and Klausner, M. (2011). "Development of the EpiOcularTM Eye Irritation Test for Hazard Identification and Labelling of Eye Irritating Chemicals in Response to the Requirements of the EU Cosmetics Directive and REACH Legislation". Altern Lab Anim, 39, 339364.

7. Nguyen, D.H, Beuerman, R.W, De Wever, B. and Rosdy, M. (2003). "Three-dimensional Construct of The Human Corneal Epithelium for in Vitro Toxicology". In: Salem, H. and Katz, S.A. (Eds), Alternative Toxicological Methods, CRC Press, pp. $147-159$.

8. McKim Jr, J.M, Keller III, D.J. and Gorski, J.R. (2012). “An in Vitro Method For Detecting Chemical Sensitization Using Human Reconstructed Skin Models and its Applicability To Cosmetic, Pharmaceutical, and Medical Device Safety Testing". Cutan Ocul Toxicol, 31, 292-305.

9. The Organisation for Economic Co-operation and Development (OECD). (2019). "Guidance Document on the Validation and International Acceptance of New or Updated Test Methods for Hazard Assessment. Environment, Health and Safety Publications". Guidelıne For Testing of Chemicals No. 431 In Vitro Skin Corrosion: Reconstructed Human Epidermis (RhE) Test Method, Paris.

10. The Organisation for Economic Co-operation and Development OECD. (2020). "Guidance Document on the Validation and International Acceptance of New or Updated Test Methods for Hazard Assessment. Environment, Health and Safety Publications". Guidelıne For Testing of Chemicals No. 439 In Vitro Skin Irritation: Reconstructed Human Epidermis (RhE) Test Method, Paris. 
11. The Organisation for Economic Co-operation and Development OECD. (2019). "Guidance Document on the Validation and International Acceptance of New or Updated Test Methods for

Hazard Assessment. Environment, Health and Safety Publications". Guidelıne For Testing of Chemicals No. 492 Reconstructed human Cornea-like Epithelium (RhCE) Test Method for Identifying Chemicals Not Requiring Classification and Labelling for Eye Irritation or Serious Eye Damage, Paris.

12. Desprez, B, Barroso, J, Griesinger, C, Kandárová, H, Alépée, N. and Fuchs H.W. (2015). "Two Novel Prediction Models İmprove Predictions of Skin Corrosive Sub-Categories by Test Methods of OECD Test Guideline No. 431". Toxicol In Vitro, 29 (8), 2055-2080.

13. Kandarova, H, Willoughby, J.A, De Jong, W.H, Letasiova, S, Milasova, T, Bachelor, M.A, Breyfogle, B, Handa, Y, De la Fonteyne, L. and Coleman, K.P. (2018). "Pre-validation of an in Vitro Skin İritation Test for Medical Devices Using The

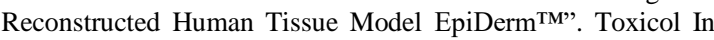
Vitro, 50, 407-417.

14. Koll, S.N, Sauer, U.G, Rey Moreno, M.C, Teubner, W, Wohlleben, W. and Landsiedel, R. (2016). "Eye Irritation Testing of Nanomaterials Using The Epiocular ${ }^{\mathrm{TM}}$ Eye Irritation Test and The Bovine Corneal Opacity and Permeability Assay". Particle and Fibre Toxicology, 13, 18.

15. Yun, J.W, Hailian, Q, Na, Y, Kang, B.C, Yoon, J.H, Cho, E.Y, Lee, M, Kim, D.E, Bae, S, Seok, S.H. and Lim, K.M. (2016) "Exploration and Comparison of in Vitro Eye Irritation Tests with The ISO Standard in Vivo Rabbit Test for The Evaluation of The Ocular Irritancy of Contact Lenses". Toxicol In Vitro, $37,79-87$. 